\title{
Attack Density and Distribution of Dendroctonus micans (Kugelann) in Standing and Felled Oriental Spruce Trees
}

\author{
*Gonca Ece ÖZCAN ${ }^{1}$ Hazan ALKAN AKINCI ${ }^{2}$ Mahmut EROĞLU ${ }^{3}$ \\ ${ }^{1}$ Kastamonu University, Faculty of Forestry, Department of Wildlife Ecology and Management, 37150 \\ Kastamonu, Turkey \\ ${ }^{2}$ Artvin Çoruh University, Faculty of Forestry, Department of Forestry Engineering, 08000, Artvin, Turkey \\ ${ }^{3}$ Karadeniz Technical University, Faculty of Forestry, Department of Forestry Engineering, 61080, Trabzon, \\ Turkey \\ "Corresponding autor: goncaece@ kastamonu.edu.tr
}

Geliş tarihi: 26.07.2016

\begin{abstract}
The aim of this study is to investigate attack density and distribution of Dendroctonus micans (Kugelann) (Coleoptera: Curculionidae) in standing and felled oriental spruce, Picea orientalis (L.) Link., trees. For this purpose, a total of 179 standing and 38 felled trees were evaluated. D. micans attacks largely concentrated in the initial several meters of the boles and particularly in the initial $1 \mathrm{~m}$ part of both tree groups. $62.53 \%$ and $67.22 \%$ of EHs in the initial $2 \mathrm{~m}$ of boles of standing and felled trees, respectively were counted in the initial 1 meter. In felled trees, the ratios of entrance holes per meter up to the initial $9 \mathrm{~m}$ of boles were similar to each other (\%7.02-9.24), other than the significant difference in the initial 1 meter $(18.96 \%)$. Above nine meters, the ratio of entrance holes per meter of boles varied in the range of $0.54 \%$ to $3.64 \%$. In the case of standing trees, unsuccessful entrances comprised $23.40 \%$ of the total entrances. In the case of felled trees, approximately one in every four entrance holes in the bole section up to the initial $8 \mathrm{~m}$ was unsuccessful, as similar to standing trees, whereas one in every three EHs in upper sections was unsuccessful.
\end{abstract}

Key Words: Oriental spruce, Geater european spruce bark beetle, Attack density

Dendroctonus micans (Kugelann)'ın Dikili ve Kesilen Doğu Ladini Ağaçlarındaki Saldırı Yoğunluğu ve Dağılımı

Özet

Bu çalışmanın amacı, Dendroctonus micans (Kugelann) (Coleoptera: Curculionidae)'ın dikili ve kesilen doğu ladini, Picea orientalis (L.) Link., ağaçlarındaki saldırı yoğunluğu ve dağılımının araştırılmasıdır. Bu amaçla, 179 dikili ve 38 kesilmiş ağaç değerlendirilmiştir. D. micans saldırıları, her iki ağaç grubunda da büyük ölçüde ağaç gövdelerinin ilk birkaç metresinde ve özellikle de ilk 1 m'sinde yoğunlaşmıştır. Dikili ve kesilen ağaçların ilk 2 m'sindeki giriş deliklerinin $\% 62,53$ 'ü ve $\% 67,22$ 'si sırasıyla dikili ve kesilen ağaçların ilk 1 m'lik kısmanda sayılmıştır. Kesilen ağaçlarda, ağaç gövdelerinin ilk 9 metreye kadar her bir metresindeki giriş deliklerinin oranı ilk 1 metredeki belirgin farkın $(\% 18,96)$ dışında birbirine daha yakın $(\% 7.02-9,24)$ oranlardadır. Dokuz metreden yukarıda, gövdelerin her bir metresindeki giriş deliklerinin oranı \%0,54 ile \%3,64 arasında değişmektedir. Dikili ağaçlarda, başarısız girişler giriş deliklerinin toplamının \%23,40'ını oluşturmaktadır. Kesilen ağaçlarda, ağaç gövdelerinin ilk 8 m'lik kısmında, dikili ağaçlara benzer şekilde, her dört giriş deliğinden yaklaşık biri, daha üst bölümlerde ise her üç giriş deliğinden biri başarısızdır.

Anahtar Kelimeler: Doğu ladini, Dev kabuk böceği, Saldırı yoğunluğu

\section{Introduction}

The greater European spruce bark beetle, Dendroctonus micans (Kugelann) (Coleoptera: Curculionidae) is found in natural as well as man-influenced spruce forests throughout Eurasia (Grégoire, 1988). It has been reported that $D$. micans females can successfully invade apparently healthy spruce trees unlike the individuals of other
Dendroctonus species which massively attack and kill trees (King and Fielding, 1989). Among bark beetles that attack living trees, a common strategy to exhaust the hosts' defences is a pheromone-mediated massattack (Lieutier, 2007).

However, D. micans neither uses aggregation pheromones to coordinate its attacks nor has any pathogenic fungi that are 
characteristic of many bark beetles (Everaerts et al., 1988). Solitary females attack trees and may end up establishing a successful brood irrespective of tree mortality (Storer et al., 1997).

D. micans is the European counterpart of a few bark beetle species which have developed a solitary attack strategy. It is capable of attacking any tree, even healthy ones. Moreover, a tree under successful attacks does not die and hence future generations can benefit from a successfully colonized tree, except during outbreaks (Grégoire, 1985; Vouland, 1991; Gilbert et al., 2001; Lieutier, 2007). It was demonstrated that trees attacked by $D$. micans are randomly distributed in a forest plot and may suffer several years of frequent attack (Gilbert, 2001). Beetles can attack trees several times but adjacent and nearby trees may remain unattacked, and attacked trees may either suffer or escape further successful attacks (Bevan and King, 1983). In oriental spruce, Alkan-Akınc1 et al. (2014) reported a limited number of attacks for many attacked trees (1-5 attacks on a tree) but significantly higher numbers (40-160 attacks on a tree) for certain trees. Certain areas and trees are highly susceptible to attacks which can reach epidemic levels (Eroğlu, 1995).

Economically important quality losses can happen in the wood of attacked trees depending on attack density (Alkan-Akınc1 et al., 2009). Presence of abundant resin exudation and resin tubes in attacked boles allows determination of $D$. micans attacks externally (Fielding and Evans, 1997; AlkanAkınc1 et al., 2010). However, it is difficult to guess attack rates and success in upper sections of trees by direct observation. The aim of this study is to make a contribution to the understanding of the solitary attack strategy of $D$. micans by investigating attack density and distribution of the beetle in standing and felled trees. Results will contribute to former studies in Turkey of which performed on standing trees, and integrated pest management strategies.

\section{Materials and Methods}

This study was conducted on oriental spruce stands infested by Dendroctonus micans in Macka Forestry Administration, Yeşiltepe and Macka Forest Sub-District Directorates in Eastern Black Sea Region, Turkey. A total of 179 standing and 38 felled trees in the study areas were evaluated. In these trees, 4090 entrance holes (EH) of $D$. micans and 5258 D. micans individuals in different biological stages were counted in galleries. The number of EHs that were at the bottom and root collars of felled trees were also counted and added to the total number belonging to the same tree.

The numbers of EHs on the bole up to 2 $\mathrm{m}$ above the ground of standing trees and on the entire bole of felled trees were counted and their heights on the bole were measured with a tape measure. It was decided whether EHs have been successful based on whether there are at least any egg systems or more mature brood systems under the bark. The bark on active galleries of $D$. micans was carefully moved using a small ax and the number of eggs, larvae, pupae and adults of the beetle was counted. Watercolor brushes, pincers and small plastic boxes were used to collect and count the beetles from their galleries. A chainsaw was used to cut down trees. The number of EHs on the bole up to 1 and $2 \mathrm{~m}$ above the ground of standing trees and the number of those on the initial 1 and 2 $\mathrm{m}$ of the bole and the entire bole of felled trees were also recorded.

In statistical procedures conducted for this purpose, logarithmic transformation was applied to the total number of EHs, which were counted on the entire bole of felled trees and which do not show normal distribution. Independent samples t-test was applied in order to identify if there is any statistical difference between mean total number of EHs counted in the initial 1 and 2 $\mathrm{m}$ and above $2 \mathrm{~m}$ of felled trees.

\section{Results}

\section{Attack density in standing trees}

A total of $2608 \mathrm{EHs}$ were counted in boles up to $2 \mathrm{~m}$ above the ground of 179 standing trees, with an average EH number of 14.57 counted for each tree (Figure 1). Mean numbers of EHs up to $1 \mathrm{~m}$ and 1 to 2 
$\mathrm{m}$ above the ground were 9.11 and 5.46, respectively. Only 130 standing trees had $12.55 \mathrm{EHs}$ on average per tree up to $1 \mathrm{~m}$ above the ground. In that case, the mean number of EHs in standing trees up to $2 \mathrm{~m}$ above the ground was 14.57, with that up to $1 \mathrm{~m}$ being 9.11 or 12.55 .

In these boles, the total number of successful EHs and the total of number of unsuccessful EHs were 1998 and 610, respectively. The mean number of successful EHs was 11.16 (1-116), with the mean number of unsuccessful EHs being 3.41 (134 ) up to 2 meters above the ground. The percentages of trees with successful and unsuccessful EHs were $89.39 \%$ and $60.34 \%$, respectively. Unsuccessful entrances made up $23.40 \%$ of the total entrances. $22.93 \%$ of the EHs were new holes, which were made in the year of the study. $77.07 \%$ of the EHs resulted from activities of the beetle in previous years. While $78.61 \%$ of the EHs of the previous years were successful, $21.39 \%$ failed. $69.90 \%$ of new entrances were successful, whereas $30.10 \%$ failed.

\section{Attack density in felled trees}

A total of 1482 EHs were counted in 38 felled trees attacked by Dendroctonus micans. $18.96 \%$ of the total number of EHs was counted in 0 to $1 \mathrm{~m}$ of felled trees, whereas $9.24 \%$ in 1 to $2 \mathrm{~m}$. The mean numbers of EHs up to $1 \mathrm{~m}$ and in 1 to $2 \mathrm{~m}$ of these trees were 7.40 (Figure 1) and 3.61, respectively (Table 1). A total of 418 EHs were counted up to $2 \mathrm{~m}$ of these trees, with the mean number of EHs being 11.01 per tree. Figure 1 shows the average number of EHs and their percentages on every one meter height of boles of felled trees and also first two meters of standing trees.

A total of 1075 successful and 407 unsuccessful EHs were counted in the felled trees. The mean number of successful EHs was 28.29 (6-97) in the felled trees, with the mean number of unsuccessful EHs being 11.31 (1-40). There were successful entrances in all felled trees, while successful entrances were detected in $94.74 \%$ of the trees. In that case, the mean number of failed EHs in all trees was 11.30. Unsuccessful entrances comprised $27.46 \%$ of the total entrances.
$41.77 \%$ of the EHs were new entrances opened in the year of the study and $58.23 \%$ of the EHs resulted from activities of the beetle in previous years. $72.21 \%$ of new EHs were successful, $27.79 \%$ were unsuccessful, whereas $72.77 \%$ of EHs of previous years were successful and $27.23 \%$ were unsuccessful. $75.80 \%$ of EHs up to $1 \mathrm{~m}$ and $77.03 \%$ of EHs up to $2 \mathrm{~m}$ of felled trees were successful, whereas $24.20 \%$ of EHs up to 1 $\mathrm{m}$ and $22.97 \%$ of EHs up to $2 \mathrm{~m}$ of felled trees were unsuccessful, respectively

The height of felled trees varies in the range of 14 to 25 meters (Figure 2). The highest points at which successful and unsuccessful EHs were determined were 16.5 $\mathrm{m}$ and $17.6 \mathrm{~m}$ of boles, respectively. $18.96 \%$ of EHs were counted in the initial $1 \mathrm{~m}$ of boles, while $28.21 \%$ were counted in the initial $2 \mathrm{~m}$. The attack density of D. micans was highest with a percentage of $85.56 \%$ in the initial $9 \mathrm{~m}$ of boles. The numbers of EHs counted in the boles were statistically different $(p<0.05)$. 


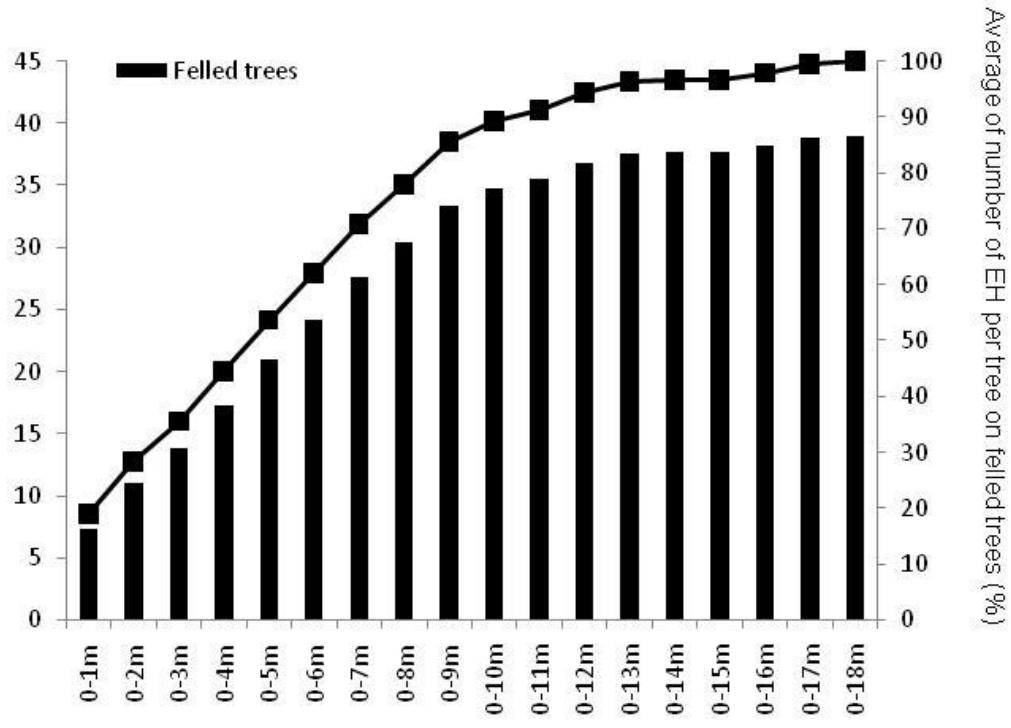

Height of trunk parts $(m)$

Figure 1. Average number of EHs and their percentages on every one meter height of boles of felled trees and also first two meters of standing trees

Table 1. The number of D. micans EHs per meter of felled trees, the mean number of EHs per tree, entrance hole percentages and cumulative percentages

\begin{tabular}{|c|c|c|c|c|}
\hline $\begin{array}{c}\text { Height of } \\
\text { bole parts (m) }\end{array}$ & $\begin{array}{c}\text { Total } \\
\text { number of } \\
\text { entrance holes }\end{array}$ & $\begin{array}{c}\text { Number of } \\
\text { entrance holes } \\
\text { average per tree }\end{array}$ & $\begin{array}{c}\text { Entrance } \\
\text { Entrance holes } \\
\text { percentages (\%) }\end{array}$ & $\begin{array}{c}\text { holes } \\
\text { cumulative } \\
\text { percentages (\%) }\end{array}$ \\
\hline $0-1$ & 281 & 7.39 & 18.96 & 18.96 \\
\hline $1-2$ & 137 & 3.61 & 9.24 & 28.21 \\
\hline $2-3$ & 109 & 2.87 & 7.35 & 35.56 \\
\hline $3-4$ & 131 & 3.45 & 8.84 & 44.40 \\
\hline $4-5$ & 137 & 3.61 & 9.24 & 53.64 \\
\hline $5-6$ & 124 & 3.26 & 8.37 & 62.01 \\
\hline $6-7$ & 131 & 3.45 & 8.84 & 70.85 \\
\hline $7-8$ & 104 & 2.74 & 7.02 & 77.87 \\
\hline $8-9$ & 114 & 3.00 & 7.69 & 85.56 \\
\hline $9-10$ & 54 & 1.42 & 3.64 & 89.20 \\
\hline $10-11$ & 29 & 0.76 & 1.96 & 91.16 \\
\hline $11-12$ & 48 & 1.26 & 3.24 & 94.40 \\
\hline $12-13$ & 28 & 0.74 & 1.89 & 96.29 \\
\hline $13-14$ & 5 & 0.13 & 0.34 & 96.63 \\
\hline $14-15$ & 0 & 0.00 & 0.00 & 96.63 \\
\hline $15-16$ & 19 & 0.50 & 1.28 & 97.91 \\
\hline $16-17$ & 23 & 0.61 & 1.55 & 99.46 \\
\hline $17-18$ & 8 & 0.21 & 0.54 & 100.00 \\
\hline Total & 1482 & 39 & 100.00 & 100.00 \\
\hline
\end{tabular}




\section{Distribution of Dendroctonus micans individuals in standing and felled trees}

There were 1185 D. micans individuals up to $2 \mathrm{~m}$ above the ground of 29 standing trees containing active galleries of D. micans. $4.56 \%$ of these individuals were adults, $14.43 \%$ were eggs, $80.25 \%$ were larvae and $0.76 \%$ were pupae.
In the entire boles of 25 felled trees, there were $4073 \mathrm{D}$. micans beetles $12.18 \%$ of which were adults, whereas $20.70 \%$ were eggs, $63.02 \%$ were larvae and $4.10 \%$ were pupae. $25.09 \%$ of these beetles were counted in the initial $3 \mathrm{~m}$ of the boles and $71.15 \%$ in the initial $9 \mathrm{~m}$ of the boles.

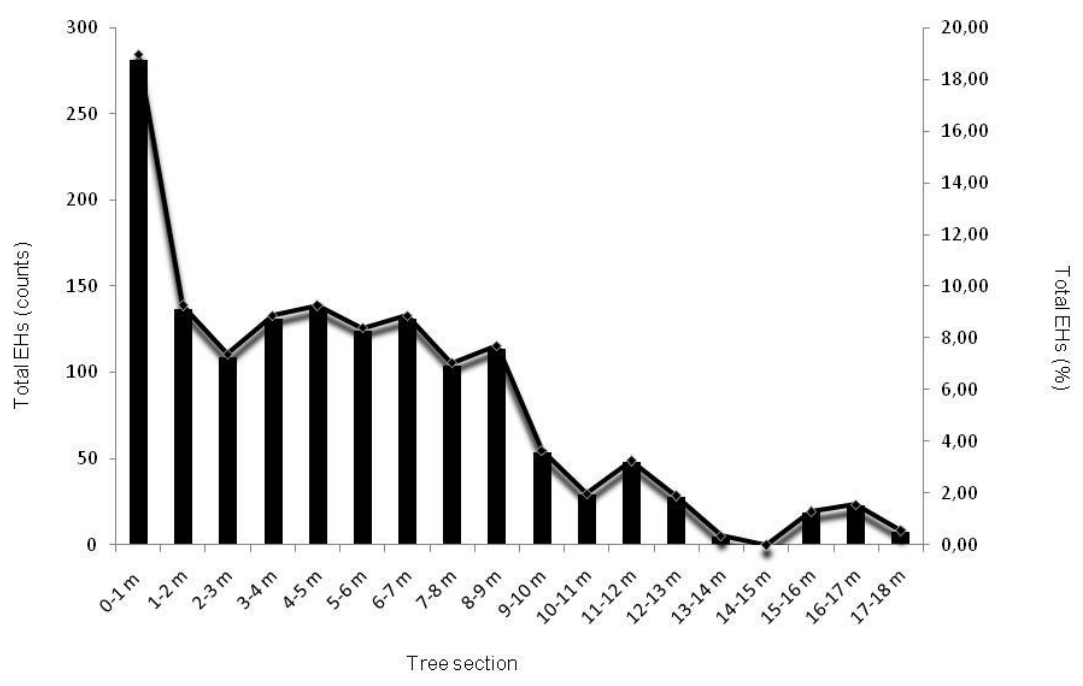

Figure 2. The mean numbers and the percentages of Dendroctonus micans EHs in each meter of boles

\section{Discussion}

It was seen that $D$. micans attacks largely concentrated in the initial several meters of the boles and particularly in the initial $1 \mathrm{~m}$ part of both tree groups. $62.53 \%$ and $67.22 \%$ of EHs in the initial $2 \mathrm{~m}$ of boles of standing and felled trees, respectively were counted in the initial 1 meter. 69\% (Eroğlu, 1995) and 61\% (Alkan-Akınc1, 2006) of EHs of D. micans in the initial $2 \mathrm{~m}$ of boles were reported in the initial 1 meter. Starting from the upper parts of the root, D. micans reproduces intensively up to $8 \mathrm{~m}$ of the bole, even at portions up to top roof (Selmi, 1998). In our study, $77.87 \%$ of EHs were in the initial $8 \mathrm{~m}$ section of the boles. Attacks of this beetle primarily start at the bottom section of boles (Eroğlu, 1995) and are concentrated in the lower section (Kobakhidze, 1967; Grégoire, 1988). In the initial stage of attacks, in some trees, attacks are more intense in the lower parts of boles, while in advanced stages of the attack, attacks can target the entire bole. D. micans attacks mostly take place in the lower parts of the bole and even in the root collars (Grégoire, 1988; Dajoz, 2000). In Georgia, $45 \%$ of attacks were reported to take place in the initial $1 \mathrm{~m}$ section of the boles (Kobakhidze, 1967).

It is possible to come across $D$. micans attacks anywhere on the bole, regardless of any special preference in terms of height. Evans et al. (1984) reported that D. micans attacks may take place in anywhere from the root to the top in the UK. In our study, successful and unsuccessful EHs were determined at 16.5 meters and 17.6 meters of boles of felled trees with heights ranging from 14-25 meters. The attack density of $D$. micans concentrated in the initial $9 \mathrm{~m}$ of boles by $85.55 \%$. The ratios of EHs per 
meter up to the initial $9 \mathrm{~m}$ of boles were similar to each other (\%7.02-9.24), other than the significant difference in the initial 1 meter $(18.96 \%)$. Above nine meters, the ratio of EHs per meter of boles varied in the range of $0.54 \%$ to $3.64 \%$.

In the standing trees, the average number of successful and unsuccessful EHs counted up to $2 \mathrm{~m}$ above the ground were 11.16 (1$116)$ and 3.41 (1-34), respectively. On entire boles of felled trees, there were 28.29 (6-97) and 11.31 (1-40) successful and unsuccessful EHs on average, respectively. There were 8.48 (1-29) and 11.31 (1-40) successful and unsuccessful EHs on average counted up to 2 $\mathrm{m}$ above the ground of felled trees.

In the case of standing trees, unsuccessful entrances comprised $23.40 \%$ of the total entrances, while in the case of felled trees; unsuccessful entrances comprised $27.46 \%$ of the total entrances. $77.03 \%$ of entrances in the initial $2 \mathrm{~m}$ of felled boles were successful, with $22.97 \%$ there of being unsuccessful. $24.3 \%$ of EHs counted in the initial $2 \mathrm{~m}$ of 501 trees infested by D. micans was unsuccessful (Alkan-Akınc1 et al., 2014).

In the case of felled trees, approximately one in every four EHs in the bole section up to the initial $8 \mathrm{~m}$, where $77.87 \%$ of $\mathrm{EHs}$ were present, was unsuccessful, as similar to standing trees, whereas one in every three EHs in upper sections was unsuccessful. This may explain why the percentage of unsuccessful entrances in the entire bole of felled trees was lower than that in the initial $2 \mathrm{~m}$ of standing trees. In the case of infested trees, increases in unsuccessful $\mathrm{EH}$ rates as a result of recurring $D$. micans attacks can be a measure of resistance developed by infested trees against the attacks of these insects. Tree resistance is reported to be the most important parameter that determines whether a female beetle is successful at colonizing a tree and laying her eggs, and can thus help to lower the population levels during the search for an available host (Lieutier, 2007).

In the case of standing trees, $22.93 \%$ of EHs in the initial $2 \mathrm{~m}$ of the boles are new entrances opened during the year of the study. $77.07 \%$ of EHs belong to activities of the beetle in previous years. $78.61 \%$ of EHs of previous years were successful, while $21.39 \%$ were unsuccessful. $69.90 \%$ of new entrances were successful, whereas $30.10 \%$ were unsuccessful. The percentage of unsuccessful entrances increased from $21.39 \%$ to $30.10 \%$. Ultimately, the success rate of the attacks carried out in the same trees decreased by $8.71 \%$ over time. It was determined that $21.66 \%$ of standing spruce trees in oriental spruce forests suffered $D$. micans attacks, however, attacks of this insect continued in $10.57 \%$ of these trees over time (Alkan-Akınc1 et al., 2014). Over the years, certain trees which have suffered repeated attacks of this insect strengthen their defenses against new attacks. The possibility of unsuccessful attacks in the case of individual $D$. micans attack can increase tree resistance (Lieutier, 2007), and some of the attacked trees develop a strong defense against new attacks and may remain viable for many years (Bevan and King, 1983).

The average numbers of successful and unsuccessful EHs counted in the initial $2 \mathrm{~m}$ of standing boles were 11.16 and 3.41 , respectively, whereas those in the case of felled boles were 8.48 (1-29) and 2.53, respectively. In oriental spruce, the attack density of $D$. micans on the first 8 meter of the bole is reported to be limited for many attacked trees (1-5 attacks on a tree) but significantly high (40-160 attacks on a tree) for certain trees (Alkan-Akınc1, 2006; AlkanAkınc1 et al., 2014). A single D. micans female is known to attack spruce trees and establish a successful brood irrespective of tree mortality (King and Fielding, 1989; Storer et al,. 1997). Hence future generations can still benefit from a successfully colonized tree, except during outbreaks (Grégoire, 1985; Vouland, 1991; Gilbert et al., 2001; Lieutier, 2007). Attacked trees are reported to suffer several years of frequent attack by beetles (Gilbert, 2001). Certain areas and trees are highly susceptible to attacks which can reach epidemic levels (Eroğlu, 1995).

$44.82 \%$ of the trees under D. micans attacks in standing trees were found to have adults and $58.62 \%$ were found to have larvae. $68.52 \%$ of the adults were counted on 4 trees, $68.24 \%$ of the larvae on 2 trees and all of the eggs were counted on 2 trees. $80 \%$ of felled trees were found to have adults and larvae. $64.11 \%$ of the adults were detected on 
2 trees, $58.67 \%$ of the larvae were detected on 3 trees and all of the eggs were detected on 3 trees. Clustering, to a certain extent, of attacks in these trees, is associated with a tendency of adult beetles to remain in the trees in which they complete their development. Gilbert et al. (2001) observed that young females create new egg galleries in the interior of the gallery system in which they have developed; mature beetles fly from the tree in which they have developed, and then return to the same tree.

In wood of trees attacked by D. micans, quality losses occur depending on the intensity of attacks that can reach economically important levels (Alkan-Akınc1 et al., 2009). Indeed, in some trees, the intensity of attacks in the initial few meters of the bole remain at a limited level of 1 to 5 attacks per tree, but it can also reach a very high level such as 40-160 per tree (AlkanAkınc1, 2006; Alkan-Akınc1 et al., 2014). Ultimately, attacks of this insect are concentrated on specific areas and certain trees (Eroğlu, 1995). Therefore, it is important to fell the least number of individuals "suitable for felling" among the attacked trees. In the case of stands under $D$. micans attack, in order to prevent aggravation of regeneration conditions, it is preferred that certain trees which have suffered attacks to a lesser extent and have a higher chance of living are allowed to stay for a longer period. In the case of oriental spruce stands, felling too many trees from an area earlier than their time of cutting would result in deterioration of closure and accordingly, the area going wild rapidly and aggravation of regeneration conditions. This gives rise to very significant challenges increasing the cost in regeneration works (Eroğlu et al., 2005). Therefore, determination of in the case of which attack the attacked trees should be cut without giving the opportunity to further deterioration of wood quality is an important issue.

Quality losses depending on attack density in wood of trees that have suffered D. micans attack can reach levels that are economically important (Alkan-Akıncı et al., 2009). Presence of abundant resin exudation and resin tubes in attacked boles allows determination of D. micans attacks externally (Fielding and Evans, 1997; Eroğlu et al., 2010). However, it is difficult to guess attack rates and success in upper sections of trees by direct observation. But the results of this study showed that the majority of EHs were up to 5-6 $\mathrm{m}$ on the felled trees. Massive attack of the beetle up to these heights on the boles can be observed by foresters in the attacked stands. Beetle's behaviour to attack lower parts of the trees ease to figure out heavily infested trees and biological and mechanical control applications.

\section{Acknowledgments}

This study was supported by a research grant from the Karadeniz Technical University (Project No. 2004.113.001.6)

\section{References}

Alkan-Akınc1, H., 2006. Doğu Ladini Ormanlarında Dendroctonus micans (Kugelann)'ın Populasyon Dinamiğine Etki Eden Etmenler ve Ips typographus (Linnaeus) ile Diğer Kabuk Böceği Türleri (Coleoptera, Scolytidae)'nin Populasyon Düzeyleri ve Etkileşimleri. Doktora Tezi, KTÜ., Fen Bilimleri Enstitüsü, Trabzon.

Alkan-Akınc1, H., Özcan G.E., Eroglu M., 2009. Impacts of site effects on losses of oriental spruce during Dendroctonus micans (Kug.) outbreaks in Turkey. Afr. J. Biotechnol. 8 (16), 3934-3939.

Alkan-Akınc1, H., Eroğlu, M., Özcan, G.E., 2010. Ladin Ormanlarımızda Rhizophagus Grandis (Gyllenhal)'in Dendroctonus micans (Kugelann) Popülasyonlarına Yerleşmesi ve Predatörün Kolonizasyon Düzeyleri. Kastamonu Üniversitesi Orman Fakültesi Dergisi, 10 (2): 137-146.

Alkan-Akınc1, H., Eroğlu M., Özcan G.E., 2014. Attack strategy and development of Dendroctonus micans (Kug.) (Coleoptera: Curculionidae) on oriental spruce in Turkey. Turkish Journal of Entomology 38 (1): 31-41.

Bevan, D. and King, C.J., 1983. Dendroctonus micans Kug. - A New Pest of Spruce in The U.K. Commonwealth Forestry Review, 62, 41-51.

Dajoz, R., 2000. Insects and Forests, Intercept Ltd., Londres-Paris-New York.

Eroğlu, M., 1995. Dendroctonus micans (Kug.) (Coleoptra, Scolytidae)'ın Populasyon Dinamiğine Etki Eden Faktörler Üzerine Araştırmalar. I. Ulusal Karadeniz Ormancılık Kongresi, Ekim, Trabzon, Bildiriler, 3, 148-159. 
Eroğlu, M., Alkan-Akıncı, H., Özcan, G.E., 2005. Ladin Ormanlarımızda kabuk böceği yıkımlarına karşı izlenebilecek kısa ve uzun dönemli mücadele ve iyileştirme çalışmaları. Ladin Sempozyumu, 20-22 Ekim 2005, Trabzon, Bildiriler Kitab1, I. Cilt, 184-194.

Eroğlu, M, Alkan-Akıncı, H., Keskin, S., 2010. Ladin ormanlarımizda Dendroctonus micans (Kug.)'1n biyolojik mücadelesinde doğal denge. Tabiat ve İnsan, 44, 11-18.

Evans, H. F., King, C. J. and Wainhouse, D., 1984. Dendroctonus micans (Kug.) in The United Kingdom. The Result of Two Years Experience in Survey and Control. Proceedings of The EEC Seminar Biological Control of Bark Beetles (Dendroctonus micans). 3-4 October 1984, Brussels, Belgium, 20-34.

Everaerts, C., Grégoire, J.C. and Merlin, J., 1988. The toxicity of Norway spruce monoterpenes to two bark beetle species and their associates. In Mechanisms of Woody Plant Defenses Against Insects (ed. by W. J. Mattson, J. Lévieux and C. Bernard-Dagan), Springer Verlag, New York, 335-344.

Fielding, N.J. and Evans, H.F., 1997. Biological Control of Dendroctonus micans (Scolytidae) in Great Britain. Biocontrol News and Information, 18, 2, 51-60.

Gilbert, M., 2001. Spatial Ecology of Dendroctonus micans (Kug.) (Coleoptera: Scolytidae). PhD dissertation, Université Libre De Bruxelles, Faculté des Sciences, Laboratoire de Biologie animale et cellulaire, Brussels, Belgium.

Gilbert, M., Vouland, G. and Grégoire, J.C., 2001. Past Attacts Influence Host Selection By The Solitary Bark Beetle Dendroctonus micans, Ecological Entomology, 26, 133-142.

Grégoire, J.C., 1985. Host Colonization Strategies in Dendroctonus: Larval Gregariousness or Mass Attack by Adults. In The Role of the Host in the Population Dynamics of Forest Insects (ed. By L. S. Safranyik), 147-154.

Grégoire, J.C., 1988. The Greater European Spruce Beetle, Dendroctonus micans. In Dynamics of Forest Insect Populations: Patterns, Causes, Implications, Plenum Press, New York, 456-478.

Khobakhidze, D.N., 1967. Dev Soymuk Böceği (Dendroctonus micans Kugel.) Gürcistan'da Çeviren Prof.Dr.Gafur Acatay. Ormancılık Araştırma Enstitüsü Dergisi 14, 2, 310.

King, C.J. and Fielding, N.J., 1989. Dendroctonus micans in Britain-its biology and control, . Forestry Commission Bulletion No 85, $1-11$.
Lieutier, F., 2007. Host resistance to bark beetles and its variations. Lieutier F, Day KR, Battisti A, Grégoire JC, Evans HF (ed) Bark and Wood Boring Insects in Living Trees in Europe, a Synthesis, Springer, Dordrecht, pp 135-180.

Selmi, E., 1998. Türkiye Kabuk Böcekleri ve Savaşı, İstanbul Üniversitesi Yayın No: 4042, emek Matbaacılık, İstanbul, 196s.

Storer, A.J., Wainhouse, D. and Speight, M.R., 1997. The Effect of Larval Aggregation BGDaviour on Larval Growth of The Spruce Bark Beetle Dendroctonus micans, Ecological Entomology, 22, 109-115.

Vouland G., 1991. Le dendroctone de l'épicéa: Dendroctonus micans (Col. Scolytidae) dans le Massif central. Dissertation, Université d'AixMarseille III. 